Proc. Indian Acad. Sci., Vol. 88 A, Part II, Number 1, March 1979, pp. 7-17, (3) printed in India

\title{
Rb-Sr age of Godhra and related granites, Gujarat, India
}

\author{
K GOPALAN, J R TRIVEDI, S S MERH*, P P PATEL * and \\ S G PATEL* \\ Physical Research Laboratory, Ahmedabad 380009 \\ * Department of Geology, M.S. University of Baroda, Baroda 390002 \\ MS received 1 September 1978; revised 1 January 1979
}

\begin{abstract}
Rubidium and strontium determinations are reported for Godhra and geographically related granites from central Gujarat. The whole rock data define a $\mathrm{Rb}-\mathrm{Sr}$ isochron corresponding to a common age of $955 \pm 20$ m.y. and initial $\mathrm{Sr}$ ratio of $0 \cdot 7130 \pm 0 \cdot 001$. This age is distinctly older than the age of $735 \mathrm{~m} . \mathrm{y}$. reported for the Erinpura suite of rocks from Mount Abu in western Rajasthan and from Idar in northern Gujarat. There are at least two generations of post-Delhi intrusive rocks in the Gujarat precambrian. Biotites associated with these granites have the same age as the whole-rocks within experimental error indicating the absence of significant metamorphic heating since the time of emplacement. It is significant that rocks of similar age occur in the Rajasthan Precambrian mainly in the axial zone of the Aravalli Mountains.
\end{abstract}

Keywords. Rb-Sr age; isochron; granite; precambrian.

\section{Introduction}

$\mathbf{R b}-\mathrm{Sr}$ determinations are reported here for granites from central and southern Gujarat. This work is a part of a major study aimed at the geochronological correlation of the precambrian rock formations of Gujarat with those of adjacent States. The results based on whole-rock and mineral analyses call for a revision of earlier beliefs on the correlation of these rocks.

\section{Geology}

Precambrian rocks of Gujarat consist of metasediments, gneisses and granites which outcrop mainly in its northern and central parts. These have been generally considered as the southern extension of the precambrian rocks of Rajasthan to the north. All our existing information on these rocks is mainly based on the works of Middlemiss (1921); Hobson (1926); Rama Rao (1931); Coulson (1933); Gupta (1934); Heron and Ghosh (1938); Gupta and Mukherjee (1938) and Heron (1953). 
The geological setting of the granites under report is briefly as follows. Aravalli metasediments of Rajasthan occupy quite a large tract around Baria and Santrampur in the Panchmahals District of Central Gujarat (figure 1). To the south, these Aravallis are flanked by a narrow strip of gneissic terrain beyond which lies another metasedimentary group called the Champaner group. Though the Champaner beds differ somewhat in lithology and tectonic history from the typical Aravalli supergroup rocks, the two groups have been correlated with each other (Heron 1953). The gneissic rocks separating the two metasediments have been recognised as an important entity by a number of geologists concerned with the original mapping of the region. However, their position in the regional geological sequence has not been clearly demarcated perhaps due to the difficulty of recognising clear-cut contacts between the gneissic masses and adjacent rocks. While Hobson (1926) considered the gneisses as post-champaner (post-Aravalli), Jambusaria (1970) has recognised erosional unconformity between the gneisses and Champaner beds at a number of places in Panchmahals and Chota Udepur, and therefore postulated that the gneisses may be the basement over which the Champner sediments were deposited.

The metasedimentary and gneissic rocks have been intruded by masses of precambrian granites at a number of locations. These granites have been subdivided into at least two age groups by previous workers. Those occurring in association with the gneisses and the Champaner group in the areas south of Baria (Panchmahals) and around Chota Udepur (Baroda) are supposed to be intrusive into Champners and therefore of post-Champaner but pre-Delhi age (Hobson 1926; Gupta and Mukherjee 1938). On the other hand, the extensive granites around Godhra along with those of Idar, Danta and Palanpur in North Gujarat have been correlated with the post-Delhi Erinpura granites occurring in the north on the western side and southern end of the Aravalli mountains. The term Erinpura granite has been loosely used in the past to denote most of the granites of post-Delhi age. Since more than one generation of post-Delhi intrusives have now been recognised (Crawford 1970), it is preferable to use the term, following Crawford (1975), to refer only to the Mount Abu and related granites of the same age. Mount Abu granites closely resemble that in Erinpura proper, about $60 \mathrm{~km}$ to the north in the lower hills. Granites of this general type, coarse grained and biotitic with large feldspars form the main suite of intrusive rocks in the axial zone of the Aravalli mountains.

\section{Previous geochronological work}

No geochronological data were available for the Godhra granites and those associated with the gneisses and Champaners. The only Gujarat rock for which satisfactory age data exist is the Idar granite of the Sabarkantha District of north Gujarat. The Idar granite appears to be of almost exactly the same age as the Mount Abu granites at $735 \pm 20 \mathrm{~m} . y$. (Crawford 1975). Crawford (1975) has also given the age of a sample of schist from a large pebble in the conglomerate of the Champaner group at Jaban near Chota Udepur at 950 m.y. assuming an initial $\mathrm{Sr}$ ratio of 0.700 . A granite sample intruding the Champaner group, though not precisely dated, appears to be younger than the Erinpura granites. 


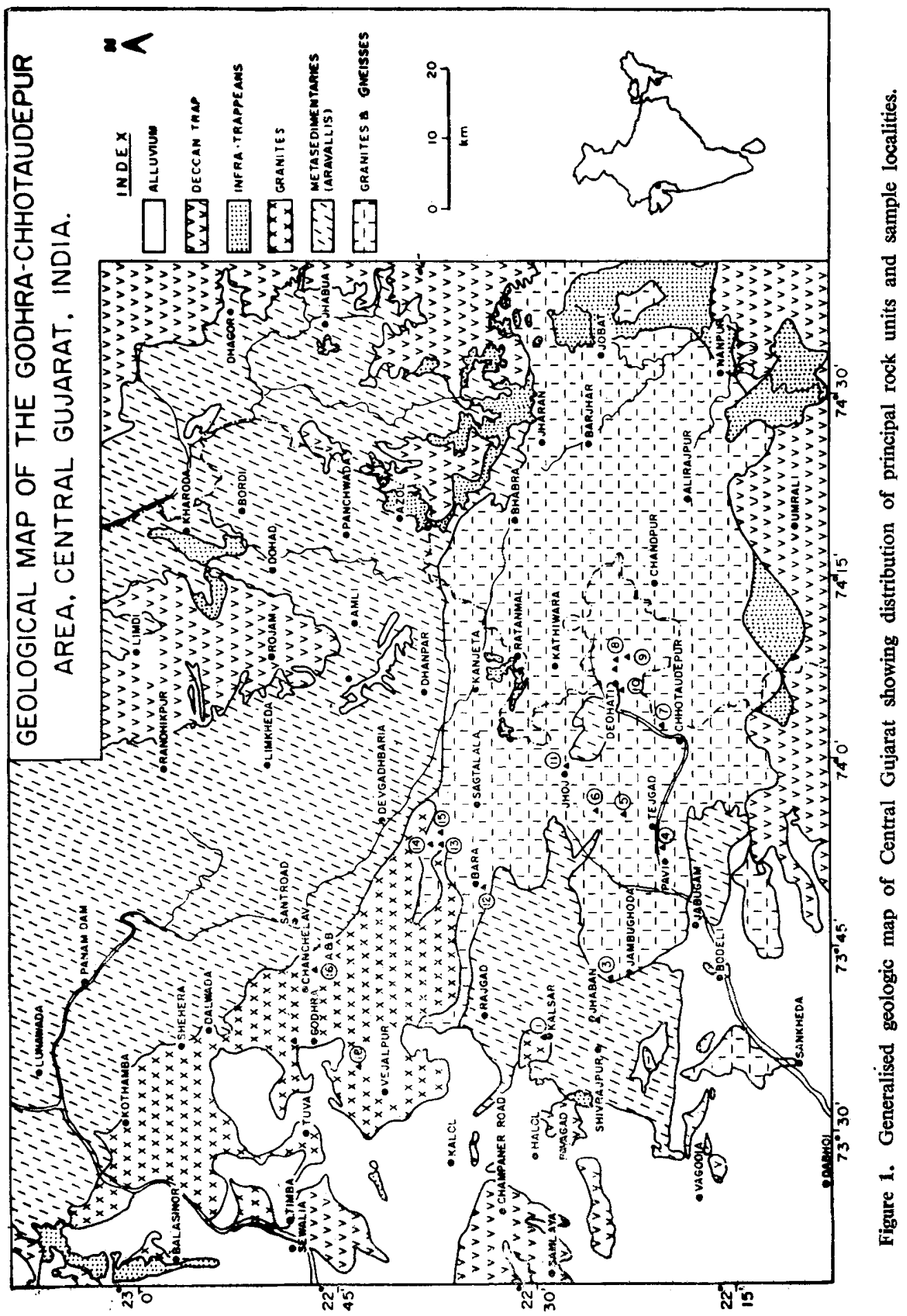




\section{Analytical procedures}

For the present investigation 16 whole-rock samples of granites have been collected from an area around Godhra, Baria and Chota Udepur. Locations of the outcrops sampled are shown in figure 1. Petrographic descriptions along with latitude and longitude of the rock samples are given in Appendix-1.

The size of whole-rock samples varied from 5 to $10 \mathrm{~kg}$. Samples were crushed and ground-up using a jaw crusher and disc grinder which were mechanically cleaned in between samples and precontaminated with small portion of the sample under processing to minimise cross contamination. The ground-up sample was well mixed and split with a riffe-type sample splitter down to about $10 \mathrm{~g}$. This portion was further ground into a fine powder with an agate mortar and pestle. Mass spectrometric analyses for $\mathrm{Rb}$ and $\mathrm{Sr}$ were carried out on about $0 \cdot 250$ to $0.500 \mathrm{~g}$ of this finely powdered and well-homogenised samples. Biotite-rich mineral fractions were separated with a magnetic separator and organic heavy liquids.

The samples were dissolved in minimal amounts of $\mathrm{HF}$ and $\mathrm{HClO}_{4}$ and evaporated inside a perspex enclosure flushed with filtered air. Between 30 to $50 \%$ of the dissolved samples were spiked with ${ }^{87} \mathrm{Rb}$ and ${ }^{84} \mathrm{Sr}$ tracers of more than $98 \%$ isotopic purity. $\mathrm{Rb}$ and $\mathrm{Sr}$ were separated on $20 \times 1 \mathrm{~cm}$ cation exchange columns using $2.5 \mathrm{~N} \mathrm{HCl}$ for elution. With the exception of pyrex glass used for the ion exchange columns and sample transfer pipette, all laboratory ware were of teflon and quartz.

The total contamination during the course of our analysis was measured by periodically running blanks in parallel with the samples. Typical blanks were $0.006 \mu \mathrm{g}$ for $\mathrm{Rb}$ and $0.008 \mu \mathrm{g}$ for $\mathrm{Sr}$, which introduce negligible error in the concentration of sample $\mathrm{Rb}$ and $\mathrm{Sr}$ normally handled.

$\mathrm{Rb}$ and $\mathrm{Sr}$ fractions were evaporated directly on to a single, precleaned tantaium filament $(0.001$ inches $\times 0.020$ inches) which served to ionise these elements in a 9-inch, 60-degree sector mass spectrometer fitted with a Faraday Collector. Mass spectra were recorded on a strip chart recorder.

The ${ }^{87} \mathrm{Rb}$ and ${ }^{84} \mathrm{Sr}$ tracer solutions were periodically calibrated by isotope dilution analysis against standard solutions of normal $\mathrm{Rb}$ and $\mathrm{Sr}$ prepared from Johnson-Mathey 'Specpure' $\mathrm{RbCl}$ and $\mathrm{SrCO}_{3}$ salts. The uncertainty in the absolute concentration of the tracer solutions is $\pm 1 \%$.

From the replicate mass analyses of the same dissolved samples and tracer calibrations at different times, the relative errors in the mass spectrometric determination of ${ }^{87} \mathrm{Rb}$ and ${ }^{86} \mathrm{Sr}$ are estimated to be $\pm 1.5 \%$ and $\pm 1 \%$ respectively, leading to a random error of not more than $\pm 2 \%$ for their ratio. $\mathrm{Rb}$ and $\mathrm{Sr}$ isotopic ratios were calculated from at least 10 contiguous sets of peak heights with standard deviations in the range of $0.1 \%$ to $0.2 \%$. ${ }^{84} \mathrm{Sr}$ tracer is so pure that ${ }^{87} \mathrm{Sr} /{ }^{86} \mathrm{Sr}$ ratio and ${ }^{86} \mathrm{Sr}$ concentration in a sample can be calculated from a single spiked $\mathrm{Sr}$ run. The ${ }^{87} \mathrm{Sr} /{ }^{86} \mathrm{Sr}$ ratios were corrected for mass fractionation assuming ${ }^{86} \mathrm{Sr} /{ }^{88} \mathrm{Sr}=0 \cdot 1194$. The long term stability of the measurement system was monitored by periodically running the NBS Sr standard (SRM 987). The ratio averaged 0.7095 with a total spread of 0.002 about this value during the period of this report. 


\section{Results and discussion}

The data for the sixteen whole-rock samples and biotite fractions separated from five of the whole-rock samples are given in table 1. The whole-rock samples show only moderate amounts of radiogenic Sr in contrast to the Mount Abu, Idar and other Erinpura type granites in the North Gujarat and Southern Rajasthan (Crawford 1975) suggesting a distinctly different geochemistry for these granite suites.

The data for all the whole-rock samples are plotted on the familiar isochron diagram given in figure 2 . The vertical side of the error boxes is the standard deviation for at least 10 contiguous sets of ${ }^{87} \mathrm{Sr} /{ }^{86} \mathrm{Sr}$ ratios, while the horizontal side represents the $\pm 2 \%$ uncertainty in the measured ${ }^{87} \mathrm{Rb} /{ }^{86} \mathrm{Sr}$ ratio. All the samples plot on a single straight line within experimental error, the straight line shown being the least squares fit of the data based on the two-error weighed regression treatment given by York (1966). This indicates that all the samples have the same age and same initial $\mathrm{Sr}$ composition as given by the slope and $Y$-intercept of this line, namely $955 \pm 20 \mathrm{~m}$.y. (assuming $1.39 \times 10^{-11} \mathrm{yr}^{-1}$ for the decay constant of ${ }^{87} \mathrm{Rb}$ ) and $0.7130 \pm 0.001$ respectively. The small scatter of the data points may either be due to incipient weathering effects seen mainly in plagioclose feldspars or to residual inhomogeneities in the samples despite the great care exercised in splitting down the large whole-rock samples.

Table 1. Analytical results

\begin{tabular}{|c|c|c|c|c|}
\hline Samples & ${ }^{87} \mathrm{Rb}, \mathrm{ppm}$ & ${ }^{86} \mathrm{Sr}, \mathrm{ppm}$ & ${ }^{87} \mathrm{Rb} /{ }^{88} \mathrm{Sr}$ & ${ }^{87} \mathrm{Sr} /{ }^{86} \mathrm{Sr}$ \\
\hline CG-3-WR & $57 \cdot 58$ & $27 \cdot 61$ & $2 \cdot 06$ & $0.7421 \pm 0.0015$ \\
\hline CG-4-WR & $45 \cdot 28$ & $53 \cdot 32$ & 0.84 & $0.7251 \pm 0.0015$ \\
\hline CG-4-BIO & $158 \cdot 5$ & $7 \cdot 30$ & $21 \cdot 45$ & $0.9808 \pm 0.002$ \\
\hline CG-5-WR & $58 \cdot 40$ & $18 \cdot 05$ & $3 \cdot 20$ & $0.7556 \pm 0.001$ \\
\hline CG-5-BIO & $231 \cdot 1$ & $5 \cdot 03$ & $45 \cdot 42$ & $1 \cdot 283 \pm 0.002$ \\
\hline CG-6-WR & $63 \cdot 65$ & $14 \cdot 65$ & $4 \cdot 29$ & $0.7707 \pm 0.001$ \\
\hline CG-7-WR & $62 \cdot 10$ & $14 \cdot 27$ & $4 \cdot 30$ & $0.7730 \pm 0.0015$ \\
\hline CG-8-WR & $54 \cdot 24$ & $36 \cdot 69$ & $1 \cdot 46$ & $0.7327 \pm 0.0015$ \\
\hline CG-8-BIO & $234 \cdot 7$ & $2 \cdot 75$ & $84 \cdot 36$ & $1.756 \pm 0.002$ \\
\hline CG-9-WR & $53 \cdot 24$ & $36 \cdot 75$ & $1 \cdot 55$ & $0.7325 \pm 0.002$ \\
\hline CG-10-WR & $58 \cdot 01$ & $52 \cdot 50$ & 1.09 & $0.7265 \pm 0.0015$ \\
\hline CG-11-WR & $50 \cdot 50$ & $17 \cdot 69$ & $2 \cdot 82$ & $0.7529 \pm 0.002$ \\
\hline CG-12-WR & $81 \cdot 07$ & $10 \cdot 56$ & $7 \cdot 59$ & $0.8144 \pm 0.0015$ \\
\hline CG-13-WR & $67 \cdot 82$ & $13 \cdot 12$ & $5 \cdot 11$ & $0.7800 \pm 0.0015$ \\
\hline CG-14-WR & $67 \cdot 75$ & $21 \cdot 41$ & $3 \cdot 13$ & $0.7551 \pm 0.0010$ \\
\hline CG-15-WR & $65 \cdot 79$ & $13 \cdot 89$ & $4 \cdot 68$ & $0.7757 \pm 0.0015$ \\
\hline CG-16A-WR & $60 \cdot 05$ & $20 \cdot 76$ & $2 \cdot 86$ & $0.7534 \pm 0.002$ \\
\hline CG-16A-BIO & $204 \cdot 3$ & $1 \cdot 12$ & $180 \cdot 30$ & $2.928 \pm 0.004$ \\
\hline CG-16B-WR & $57 \cdot 49$ & $17 \cdot 63$ & $3 \cdot 22$ & $0.7537 \pm 0.0015$ \\
\hline CG-18-WR & $69 \cdot 39$ & $21 \cdot 66$ & $3 \cdot 17$ & $0.7524 \pm 0.0015$ \\
\hline CG-18-BIO & $257 \cdot 90$ & 0.571 & $446 \cdot 2$ & $6.370 \pm 0.004$ \\
\hline
\end{tabular}




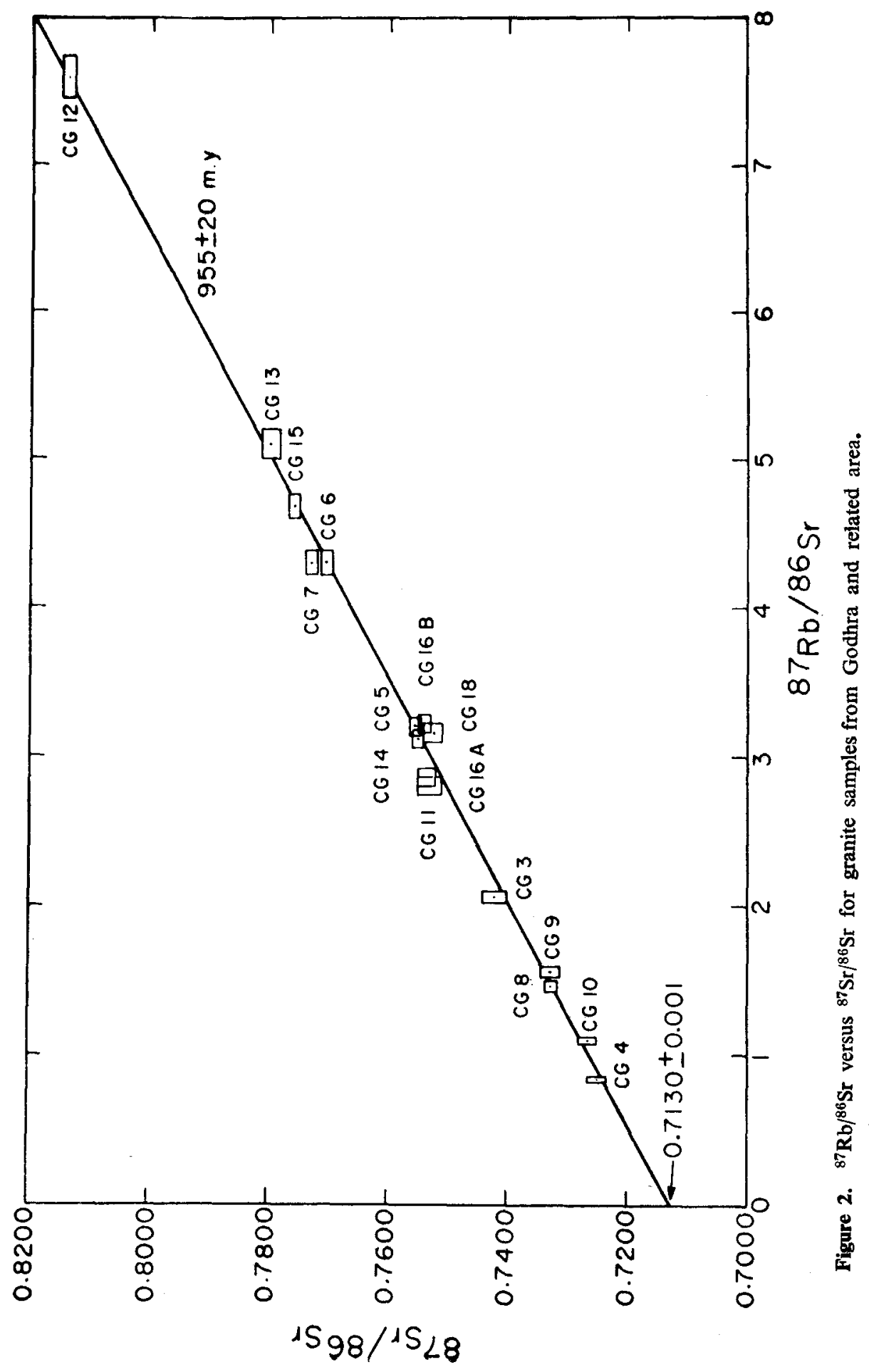


The whole-rock data for Godhra granites do not permit an independent age determination for them, as not only are the samples too few in number (16A, 16B and 18) but also they are insufficiently enriched in radiogenic Sr. A further study is planned in which the Godhra granite pluton will be sampled more extensively to provide more definite conclusions regarding these rocks. For the present, the age of the Godhra granites is inferred from the agreement of their whole-rock and biotite data with the rest of the samples included in this report.

The main result of the present work is that the distinction in age between the Godhra granites and the granites intruding the gneisses and the Champaner beds as suggested by previous workers no longer holds. The two granite suites have the same age of 955 m.y. Secondly, Crawford (1975) postulated that all granites of Gujarat have the same age as those of the Malani-Mount Abu-Idar suites. This correlation is not valid as the Godhra granites are distinctly older (by about $200 \mathrm{~m} . \mathrm{y}$.) than the latter suite with a common age of $735 \pm 30 \mathrm{~m}$.y. There are at least two generations of granites in the Gujarat precambrian at 955 and $735 \mathrm{~m} . \mathrm{y}$. respectively.

It is however significant that granites with the same or nearly the same age as the Godhra granites occur in the Rajasthan precambrian, mainly in the axial zone of the Aravalli mountains, which has been persistently mobile (Crawford 1970). There are the Ajmer granite, $935 \mathrm{~m} . \mathrm{y}$., Chhapoli granite, $1010 \mathrm{~m} . \mathrm{y}$. and the Untala granite, $955 \pm 50 \mathrm{~m} . \mathrm{y}$. The Untala granite east of the city of Udepur is not from the main axial zone but geographically close to the Central Gujarat granites. The c. $950 \mathrm{~m} . \mathrm{y}$. event therefore appears to be quite widespread over a linear tract of more than $600 \mathrm{~km}$ and is correlatable with the c. $950 \mathrm{~m} . \mathrm{y}$. granitic event in the Satpura Belt over $1000 \mathrm{~km}$ (Sarkar 1972).

Biotite fractions separated from the five whole-rock samples $4,5,8,16 \mathrm{~A}$ and 18 are well enriched in radiogenic $\mathrm{Sr}$ and give a concordant age of $900 \pm$ $40 \mathrm{~m} . \mathrm{y}$. This mineral age is not significantly different from the whole-rock age of the samples and hence shows that this granite suite has not been thermally disturbed by events subsequent to its emplacement $955 \mathrm{~m} . \mathrm{y}$. ago, and that the actual age of the Godhra granites is not significantly different from that of the granites associated with the gneisses and the Champaner group.

While the Godhra and related granites are definitely of post-Delhi age, the associated gneisses and schists may be older being either pre-Delhi (c. 1600 m.y.) or pre-Aravalli (c. $2500 \mathrm{~m} . \mathrm{y}$.). Study of these older rocks has been planned as there is a possibility that the gneisses of Central Gujarat may prove to te the equivalent of the Banded Gneissic Complex of Rajasthan. That these gneisses may be the basement over which the Champaner beds were deposited has already been suggested by Jambusaria (1970).

A sample of schist from a large pebble in conglomerate of the Champaner at Jaban near Shivarajpur gives an age of 950 m.y. assuming an initial ratio of 0.700 (Crawford 1975). This is definitely inadequate to provide reliable inference on the age of the Champaner schists. However, the near-equality of this single age of a schist sample with that of the associated granites is interesting. It does suggest the possibility that the entire basal conglomerate from which the pebble was taken has been metamorphosed since its deposition at about the same time the granites wẹre intruded. 
The granites that intrude the Champaners are so intimately mixed with the surrounding gneisses that it is difficult to clearly demarcate their boundaries. This fact led Merh (1975) to the hypothesis that the granites could be the products of mobilisation of the basement gneisses. The present data are not adequate to resolve this issue unequivocally. However, the initial $\mathrm{Sr}$ ratio of $0.7130 \pm 0.001$ observed in these rocks is higher than that typical of $\mathrm{Sr}$ from $\mathrm{Rb}$-poor sources such as modern basalts (Gast 1960; Faure and Hurley 1963; Hedge and Walthall 1963). This higher value suggests that the granite magma originated from fusion of old crustal material of higher $\mathrm{Rb}$-Sr ratio than upper mantle materials from which basalts are believed to be derived.

\section{Acknowledgements}

The authors thank Professor D Lal for his sustained interest and encouragement in the application of nuclear techniques to earth sciences. Special appreciation is due to Drs S J Desai and M P Patel (M. S. University of Baroda) for their help in collecting and processing the samples. Thanks are also due to Dr C A Sastry (Geological Survey of India) for discussions.

\section{Appendix 1}

Locations and brief descriptions of the samples

Specimen no.

Description

and location

CG-3-WR

$22^{\circ} 21^{\prime} \mathrm{N}$

$73^{\circ} 43^{\prime} \mathrm{E}$

$2 \mathrm{~km} \mathrm{~N}$ of

Jambughoda

CG-4-WR

$22^{\circ} 18^{\prime} \mathrm{N}$,

$73^{\circ} 53^{\prime} \mathrm{E}$

$1.5 \mathrm{~km} \mathrm{E}$ of

Pavi

CG-5-WR

$22^{\circ} 20^{\prime} \mathrm{N}$,

$73^{\circ} 56^{\prime} \mathrm{E}$

$4 \mathrm{~km} N E$ of

Tejgarh
Light pink, coarse-grained, porphyritic (microcline as phenocrysts); composed of 30\% quartz, $49 \% \mathrm{~K}$-feldspars (microcline and orthuclase), $17 \%$ plagioclase, $3 \%$ micas and $1 \%$ usual accessories; shows clear intrusive relation with the metasedimentaries (Champaners).

Light pinkish grey, coarse-grained, porphyritic (phenocrysts of pink microcline); composed of 35\% quartz, 33\% $\mathrm{K}$-feldspars (microcline and orthoclase), 19\% plagioclase, 12\% biotite with subordinate muscovite, $0.5 \%$ hornblende and $0.5 \%$ accessories; feldspars show incipient alteration to sericite; biotite occurring as large flakes separated for independent analysis; rock shows intrusive relationship with the gneissic country rocks.

Grey, faintly foliated, medium-grained, equigranular, composed of quartz, $\mathrm{K}$-feldspars (microcline and orthoclase with a little perthite), plagioclase (mainly oligoclase), biotite, etc., zircon and sphene are notable among the accessories. Biotite occurring in the form of large flakes separated for independent analysis. (Modal percentages not calculated). 
Specimen no.

Description

and location

CG-6-WR

$22^{\circ} 23^{\prime} \mathrm{N}$,

$73^{\circ} 30^{\prime} \mathrm{E}$

$6 \mathrm{~km} \mathrm{SW}$ of

Jhoj

CG-7-WR

$22^{\circ} 19^{\prime} \mathrm{N}$,

$74^{\circ} 30^{\prime} \mathrm{E}$

$6 \mathrm{~km} \mathrm{NE}$ of

Chota Udepur

CG-8-WR

$22^{\circ} 21^{\prime} \mathrm{N}$,

$74^{\circ} 8^{\prime} \mathrm{E}$

$3 \mathrm{~km} \mathrm{E}$ of

Deohati

CG-9-WR

$22^{\circ} 20^{\prime} \mathrm{N}$,

$74^{\circ} 8^{\prime} \mathrm{E}$

$3.5 \mathrm{~km}$ ESE

of Deohati

CG-10-WR

$22^{\circ} 20^{\prime} 30^{\prime \prime} \mathrm{N}$,

$74^{\circ} 5^{\prime} \mathrm{E}$

$1 \mathrm{~km} \mathrm{SW}$ of

Deohati

CG-11-WR

$22^{\circ} 28^{\prime} \mathrm{N}$,

$73^{\circ} 59^{\prime} \mathrm{E}$

at Jhoj

CG-12-WR

$22^{\circ} 34^{\prime} \mathrm{N}$,

$73^{\circ} 50^{\prime} \mathrm{E}$

$1 \mathrm{~km} \mathrm{SW}$ of

Bara
Light grey, massive, coarse-grained, ahriost cquigranular, composed of $36 \%$ quartz, $37 \% \mathrm{~K}$-feldsars (orthoclase, microcline and perthite), $15 \cdot 5 \%$ plagioclase, $9 \cdot 5 \%$ biotite with a little muscovite and $0.5 \%$ usual accessories (apatite and zircon).

Pinkish grey, massive, medium-grained, equigranular, composed of $32 \%$ quartz, $36 \% \mathrm{~K}$-feldspars (orthoclase and microcline with a little perthite), $21 \%$ plagioclase, $9.5 \%$ muscovite and biotite, $0 \cdot 3 \%$ hornblende and $1 \cdot 2 \%$ accessories (zircon and apatite); a little chloride appearing as an alteration product, feldspars show slight sericitisation.

Grey, showing crude gneissic foliation, medium-grained; composed of $39 \%$ quartz, $32 \% \mathrm{~K}$-feldspars (microcline, orthoclase and some showing perthitic intergrowth), $14 \%$ plagioclase, $13 \cdot 5 \%$ biotite (with a little muscovite) and $1.5 \%$ accessories (apatite and zircon); biotite separated for independent analysis.

Grey, medium-grained showing compact gneissic foliation; composed of $38 \%$ quartz, $40 \%$ K-feldspars (microcline and orthoclase), $11 \%$ plagioclase, $10 \%$ biotite and muscovite, $0.5 \%$ hornblerde and $1 \cdot 5 \%$ accessories (magnetite, zircon and apatite).

Pinkish grey, medium to coarse-grained, showing faint but compact gneissic foliation composed of $30 \%$ quartz, $50 \% \mathrm{~K}$ feldspars (microcline and orthoclase), 10\% plagioclase, 9\% biotite and muscovite and $1 \%$ accessories (zircon and apatite more common); incipient alteration of biotite to chlorite and of feldspars to sericitic mica.

Light grey, massive, medium-grained, almost equigranular, composed of $41 \%$ quartz, $34 \% \mathrm{~K}$-feldspars (orthoclase and microcline), $14 \%$ plagioclase, $9 \%$ biotite and muscovite and $2 \%$ accessories (garnet and apatite).

Light grey, massive, medium to fine grained; composed of $36 \%$ quartz, $46 \% \mathrm{~K}$-feldspars (orthoclase, microcline including perthite), $10 \%$ plagioclase, $7 \%$ biotite and muscovite, and $1 \%$ accessories (apatite and zircon). 


\section{Appendix 1 (Contd.)}

Specimen no.

Description

and location

CG-13-WR

$22^{\circ} 37^{\prime} \mathrm{N}$,

$73^{\circ} 53^{\prime} \mathrm{E}$

$6 \mathrm{~km} \mathrm{NE}$ of

Bara

CG-14-WR $22^{\circ} 38^{\prime} \mathrm{N}$, $73^{\circ} 53^{\prime} \mathrm{E}$

$7 \mathrm{~km} \mathrm{SW}$ of

Devagadbaria

CG-15-WR

$22^{\circ} 37^{\prime} \mathrm{N}$,

$73^{\circ} 54^{\prime} \mathrm{E}$

$6 \mathrm{~km} \mathrm{NW}$ of

Sagtala

CG-16A-WR

$22^{\circ} 17^{\prime} \mathrm{N}$,

$73^{\circ} 43^{\prime} \mathrm{E}$

$3 \mathrm{~km}$ ESE of

Chanchelav
Grey with specks of light pink, massive, medium-grained equigranular ; composed of $32 \%$ quartz, $47 \% \mathrm{~K}$-feldspars, $9 \%$ plagioclase, $8 \%$ muscovite and biotite, $1 \%$ hornblende, and $1 \%$ usual accessories; incipient alteration of hornblende and biotite to chlorite and of feldspars to sericitic mica.

Light grey, somewhat foliated, coarse-grained, porphyritic (phenocysts mostly of microcline which show a preferred orientation); composed of $38 \%$ quartz, $34 \% \mathrm{~K}$-feldspars (othoclase with subordinate perthitic microcline), $15 \%$ plagioclase, $12 \%$ biotite and muscovite, $0.3 \%$ hornblende and $0.7 \%$ accessorjes (zircon, apatite and some opaques).

Light pink, massive, medium to fine-grained; composed of $40 \%$ quartz, 46\% K-feldspars (microcline and orthoclase), 9\% plagioclase, $4 \%$ micas (muscovite with a little biotite), $1 \%$ accessories (apatite and zircon).

Light grey, compact, foliated, coarse-grained, almost equigranular; composed of $37 \%$ quartz, $35 \% \mathbf{K}$-feldspars (microcline, orthoclase with a little perthite), $15 \%$ plagioclase, $11 \cdot 5 \%$ micas (mostly biotite with a little muscovite) and $1.5 \%$ accessories (mostly zircon); biotite occurring as large flakes separated for independent analysis.

CG-16B-WR Very light grey, with some light greenish grey specks, massive, $22^{\circ} 47^{\prime} \mathrm{N}$, $73^{\circ} 43^{\prime} \mathrm{E}$

$3 \mathrm{~km}$ ESE of

Chanchelav

CG-18-WR $22^{\circ} 43^{\prime} \mathrm{N}$, $73^{\circ} 37^{\prime} \mathrm{E}$

$6 \mathrm{~km} \mathrm{SSW}$ of Godhra fine-grained; occurring as large irregular segregated patches in CG-16A; composed of $44 \%$ quartz, $37 \% \mathrm{~K}$-feldspars (orthoclase and perthitic microcline), $12 \%$ plagioclase, $5 \cdot 5 \%$ muscovite and biotite, $1 \%$ hornblende and $0.5 \%$ accessories (apatite, zircon, garnet and opaques).

Light grey, coarse-grained, porphyritic (phenocrysts 2 to 8 $8 \mathrm{~cm}$ of mainly microcline which show a faint preferred orientation); composed of $33 \%$ quartz, 17\% K-feldspars (mostly microcline with a little orthoclase), $34 \%$ plagioclase, $14 \cdot 5 \%$ micas (mostly biotite with a little muscovite), $1.5 \%$ accessories (mostly zircon); feldspars show incipient alteration to sericitic mica; biotite flakes separated for independent analysis.

The percentage mineral composition is given with best approximation. 


\section{References}

Coulson A L 1933 Mem. Geol. Surv. India 63

Crawford A R 1970 Can. J. Earth Sci. 791

Crawford A R 1975 J. Geol. Soc. India 1620

Faure G and Hurley P M $1963 \mathrm{~J}$. Petrol. 431

Gast P W 1960 J. Geophys. Res. 651287

Gupta B C $1934 \mathrm{Mem}$. Geol. Surv. India 652

Gupta B C and Mukherjee P N 1938 Rec. Geol. Surv. India 73163

Hedge C E and Walthall F G 1963 Science 1401214

Heron A M $1953 \mathrm{Mem}$. Geol. Surv. India 79389

Heron A M and Ghosh P K 1938 Rec. Geol. Surv. India 72367

Hobson G V 1926 Rec. Geol. Surv. India 59340

Jambusaria B B 1970 Geology of the area around Shivrajpur (Dist. Panchmahals, Gujarat) with special reference to the stratigraphy, structure and metamorphism. Unpublished Ph.D. thesis, M.S. University of Baroda

Merh S S 1975 Seminar on the recent advances in precambrian geology and mineral deposits with special reference to Rajasthan. Udaipur, Nov. 75.

Middlemiss C S $1921 \mathrm{Mem}$. Geol. Surv. India 44115

Rama Rao B 1931 The geology of Baria State (Rewakantha Agency)

Sarkar S N 1972 Proc. 24th Int. Geological Conf. Montreal, Section 1 260-272

York D 1966 Can. J. Phys. 441079 